\title{
A Case of Unicornuate Uterus Accidentally Discovered During Patient's Fourth Delivery
}

\author{
Meryem Hocaoğlu1 ${ }^{1}$, Mehmet Kanter² ${ }^{2}$ Ahmet Göçmen ${ }^{3}$
}

1'istanbul Medeniyet Üniversitesi Göztepe Eğitim ve Araștırma Hastanesi, Kadın Hastalıkları ve Doğum Kliniği, İstanbul

2istanbul Medeniyet Üniversitesi Tıp Fakültesi, Histoloji ve Embriyoloji Anabilim Dalı, İstanbul

${ }^{3}$ |stanbul Medeniyet Üniversitesi Göztepe Eğitim ve Araştırma Hastanesi, Kadın Hastalıkları ve Doğum Kliniği, İstanbul

Eur J Basic Med Sci 2015;5(4): 67-69

Received: 23-05-2016

Accepted: 20-06-2016

Correspondence (Yazıșma Adresi):

Dr. Meryem Hocaoğlu

Istanbul Medeniyet Üniversitesi

Tıp Fakültesi Göztepe E.A.H

Kadın Hastalıkları ve Doğum Kliniği

Telefon: 02164811298

E-mail: dr.meryemtaskiran@gmail.com

\begin{abstract}
Unicornuate uterus with non-communicating rudimentary horn is a rare congenital uterine malformation. It may lead to a variety of infertility and obstetric complications. A 32-year-old woman - para III gravida IV - presented at the third stage of pregnancy with acute onset of severe right abdominal pain. Cesarean delivery with abdominal exploration were performed. During cesarean section a unicornuate uterus with a rudimentary horn was accidentally observed. This is a rare and interesting clinical example of patient who had four healthy babies as results of four uneventful pregnancies despite having a unicornuate uterus which carries a significant risk of infertility and advers pregnancy outcomes.
\end{abstract}

Key Words: Cesarean section, pregnancy, unicornuate uterus

Dördüncü Doğumda Farkedilen Bir Unikornuat Uterus Vakası

\section{ÖZET}

Non-komünikan rudimenter horn ile birlikte olan unikornuat uterus nadir bir konjenital uterin anomalidir. Infertiliteye ve çok sayıda obstetrik komplikasyona neden olabilir. 32 yașında gravida IV parite III , üçüncü trimesterde bir gebe yeni başlangıçlı, șiddetli sağ abdomen ağrısı ile başvurdu. Abdominal eksplorasyon ile birlikte sezeryan ile doğum gerçekleștirildi. Doğum sırasında hastada rudimenter horn ile birlikte unikornuat uterus izlendi. Infertilite ve olumsuz gebelik sonuçları için anlamlı düzeyde risk taşımasına rağmen unikornuat uterusa sahip bir hastanın dört sağlıklı gebelik sonrası sağııkı dört çocuk sahibi olabilmesi nadir ve ilginç bir klinik durumdur.

Anahtar Kelimeler: Sezeryan ile doğum, gebelik, unikornuat uterus 


\section{INTRODUCTION}

Congenital uterine anomalies represent a distortion of the uterine anatomy due to maldevelopment of the Mullerian duct system (1). These anomalies can be found in 1 to $10 \%$ of the unselected population, 2 to $8 \%$ of infertile women and 5 to $30 \%$ of women with a history of miscarriages (2) A unicornuate uterus also called as Class IV congenital uterine anomaly constitudes a unilaterally formed uterus; it may have a communicating or non-communicating horn with cavity (IVa), or a horn without a cavity or aplasia (IVb) (3). Unicornuate uterus is significantly more common in infertile women and also may lead to obstetrical problems such as infertility, ectopic pregnancy, abortion, preterm delivery, intrauterine fetal demise, prematurity, fetal growth retardation, malpresentation (4-13). However successful pregnancies have been rarely encountered. We present a patient who had four successful deliveries after four successful pregnancies inspite of having a unicornuate uterus with a rudimentary horn.

\section{CASE REPORT}

A 32-year old unbooked, gravida IV para III woman presented at the third stage of pregnancy with acute onset of severe right abdominal pain. She had a history of two separate surgeries for cholecystitis prior to the onset of pregnancy. Examination revealed moderate abdominal wall tenderness without rebound tenderness. Routine investigations and vital signs were normal on admission.

The present pregnancy was a result of spontaneous conception. She had delivered three live births at term. Transabdominal ultrasound scan revealed one live fetus at $38 \mathrm{w}$ and the amniotic fluid was normal. Furthermore patient had no contraction, the uterus was tender and the cervix wasn't dilated.

She was consulted with general surgeons. They didn't think of acute abdomen. She was kept under observation during which she had recurrent pain despite opioid analgesics. She underwent a cesarean section with abdominal exploration. The abdominal cavity was entered through a Pfannenstiel incision. The baby was delivered through a low transverse uterine incision. She had a healthy baby boy, with an Apgar score of 9 to 10, weight of $3150 \mathrm{~g}$ and height of $49 \mathrm{~cm}$. Intraoperative findings were so strange as a unicornuate uterus with non-communicating rudi-

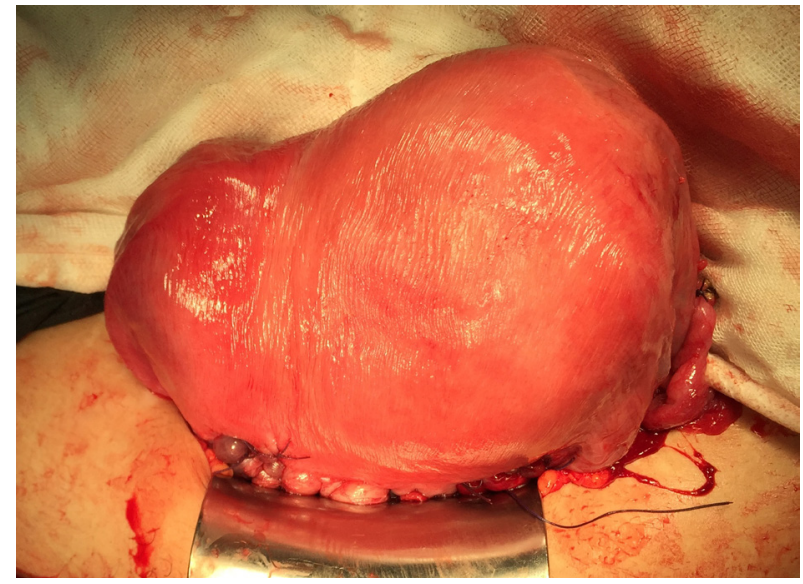

Figure 1. Perioperative view of unicornuate uterus

mentary horn was revealed (Fig. 1). Both of the ovaries and the fallopian tubes were normal. And also no more findings was observed assosiated with acute abdominal pain. The mother had no postsurgery complications

\section{DISCUSSION}

Unicornuate uterus with rudimentary horn may lead to gynecologic problems, infertility and obstetrical advers outcomes $(4,6,7)$. Reichman et al. published rates of $51.5 \%$ live birth in women with unicornuate uterus (4). Wang et al. presented 26 cases of rudimentary horn of uterus, four of which $(15 \%)$ had become pregnant, and one of which (4\%) had been presented with ipsilateral oviduct ectopic pregnancy (8). Heinonen mentioned 93 pregnancies and only two of them had term delivery. The fetal survival rate was $61 \%$ in the series of Nathan (9). Fox et al. suggested that the risk of adverse pregnancy outcomes was increased in patients with uterine unicornis and the rate of preterm birth < 37 weeks was $50 \%$ (10).

Even though the obstetrical outcome is usually poor, there are some case reports that present successful pregnancies. Nahra-Lynch et al. reported a woman with known unicornuate uterus. This patient became pregnant with twins after controlled ovarian hyperstimulation and intrauterine insemination but she had some obstetrical 
problems (11). Also Gerris et al. reported successful triplet pregnancy in a patient with a unicornuate uterus with a cavitary communicating rudimentary horn (12). Caserta et al. reported a 39 weeks and 4 days pregnancy after which they had a healthy baby via cesarean section. (13) Furthermore another case report presented a full-term pregnancy in an undeveloped auxialiary horn of uterus unicornis (14). It is remarkable that all these aforesaid case reports present patients with only one pregnancy. Thus as a contribution to the relevant literature, with four healthy children after four uneventful pregnancies this presented case points out possibility of accomplishing multiple successful pregnancies despite having a unicornuate uterus. This is a very important message both for doctors and anxious patients with unicornuate uterus as this anomaly has already been known to provoke obstetric and gynecologic problems.

\section{REFERENCES}

1. Sadek SM, Ahmad RA, Atian H. Performance of the ESHRE/ ESGE classification in differentiating anomalies of double uterine cavity in comparison with the ASRM classification. Middle East Fertility Society Journal 2016, 21:75-81.

2. Chan YY, Jayaprakasan K, Tan A, Thornton JG, Coomarasamy $A$, RaineFenning NJ: Reproductive outcomes in women with congenital uterine anomalies: a systematic review. Ultrasound Obstet Gynecol 2011, 38:371-382.

3. Grimbizis GF, Campo R. On behalf of the Scientific Committee of the Congenital Uterine Malformations (CONUTA) common ESHRE/ESGE working group, Gordts S, Brucker S, Gergolet M, Tanos V, Li T-C, De Angelis C, Di Spiezio Sardo A: Clinical approach for the classification of congenital uterine malformations. Gynecol Surg 2012, 9:119-129.
4. Reichman $D$, Laufer MR, Robinson BK. Pregnancy outcomes in unicornuate uteri: a review. Fertil Steril 2009 91(5):1886-94.

5. Hua M, Odibo AO, Longman RE, Macones GA, Roehl KA, Cahill AG. Congenital uterine anomalies and adverse pregnancy outcomes. Am J Obstet Gynecol 2011; 205:558.e1-5.

6. Fedele $L$, Zamberletti D, Vercellini P, Dorta M, Candiani $G B$. Reproductive performance of women with unicornuate uterus. Fertil Steril 1987; 47(3):416-9.

7. Akar ME, Bayar D, Yildiz S, Ozel M, Yılmaz Z. Reproductive outcome of women with unicornuate uterus. Aust N Z J Obstet Gynaecol 2005;45(2):148-50.

8. Wang SJ, Oli M, Jinag L, Wang JL, Wei LH. Clinical analysis of 225 women with congenital uterine malformation. Zhonghua Fu Chan Ke Za Zhi. 2008;43(7):493-6.

9. Heinonen PK. Unicornuate uterus and rudimentary horn. Fertil Steril 1997;68(2):224 30.

10. Nathan S. Fox, Ashley S. Roman, Erica M. Stern, Rachel S. Gerber, Daniel H. Saltzman \& Andrei Rebarber. Type of congenital uterine anomaly and adverse pregnancy outcomes. The Journal of Maternal-Fetal \& Neonatal Medicine, 27:9, 949-953.

11. Nahra-Lynch M, Toffle RC. Multiple gestation in a unicornuate uterus. A case report. J Reprod Med. 1997;42(7):451-4.

12. Gerris $J$, Eulaers $E$, Joostens $M$, Jacquemyn $Y$, Loquet $P$, Verdonk $P$, Buytaert $P$. Successful triplet pregnancy in a patient with a unicornuate uterus with a cavitary communicating rudimentary horn. Hum Reprod 1993; 8(2):338-41.

13. Caserta D, Mallozzi M, Meldolesi C, Bianchi P, Moscarini M. Pregnancy in a unicornuate uterus: a case report. Journal of Medical Case Reports 2014; 8:130.

14. Domanski S. Full-term pregnancy in undeveloped auxialiary horn of uterus unicornis. Ginekol Pol. 1957; 28(2):139-42. 